\title{
THE GHEMISTRY OF SOME NEW ANALGETICS
}

\author{
George deStevens \\ CIBA Pharmaceutical Company, Summit, New Jersey, U.S.A.
}

\section{INTRODUGTION}

In the period between January 1964 and June 1965, I was most fortunate in having been engaged in a collaborative effort with a number of highly capable people in bringing forth an edited work entitled Analgetics ${ }^{1}$. This work had as its goal to bring together between two covers the pertinent knowledge on the chemistry, pharmacology and clinical aspects of analgetics up to early 1965. Therefore, it is the purpose of these introductory comments to consider that the information on analgetics accrued up to 1965 to be essentially documented in the monograph just mentioned. In so doing our discourse will concern itself principally with the new body of knowledge which has become evident within the past three years; however, it is obvious that the knowledge of the past must form a necessary backdrop for the enfolding events of the present and future. To this end some basic concepts and definitions are in order.

All animal species are capable of experiencing pain although the degree to which individuals react to this phenomenon is relative. This then refers to what is generally known as the pain threshold. It is that minimum level at which an animal, man or otherwise, responds to a painful stimulus. Obviously, the psychic influence to such a reaction is most important. Whether or not a lower animal realizes the full significance of exogenous induced pain and is able to associate this with environmental factors and at the same time relate this stimulus with pain resulting from a pathological disorder is a philosophical point. However, man does know the difference and is able to relate and distinguish them both to their immediate effect on his well-being and also as in the case of pathological pain, to his ultimate demise. Thus, the psychological effect on man experiencing pain is conditioned by the intrinsic nature of this stimulus. No doubt the impact of the stimulus on his mental and physical well-being is not without profound effects. These fine distinctions cannot be made, as far as we know, by the lower animals. It is for this reason that the laboratory study of pain and the alleviation of pain by means of drugs in experimental animals has proceeded so slowly. In fact, all we can note with animals is a response to an outside stimulus which we define as a reaction to pain. From these experiments we then seek to obtain an analgetic agent which is defined as a drug which depresses pain without loss of consciousness. Dr. Winter (the preceding lecture) has already referred to the various laboratory methods employed for detecting analgetic compounds in animals but none of these can truly be considered adequate. It is probably for this reason that the literature abounds with references to new analgetics. In a recent 
survey of Chemical Abstracts it was noted that more references were made within the past three years to new analgetic agents than to any other single area of medicinal agents. And yet, this area is the one in which the number of new drugs has not been forthcoming commensurate with the intellectual and experimental inputs. Nevertheless, the search still continues and hopefully towards what $\mathrm{Pfeiffer}^{2}$ has termed the ideal analgetic. It should be effective against all types of pain, but not alter other sense receptors; it should have a large therapeutic margin of safety, a rapid onset and a long duration of action. It should not depress the cardiovascular and respiratory systems; should not affect the gastrointestinal tract; should be effective orally and parenterally; should not act as an antidiuretic; should be inexpensive to manufacture and be chemically stable; and above all, should not lose its effectiveness through the development of tolerance which in turn may lead to habit formation or addiction. The development of a drug with all of these properties is truly a monumental task but is not necessarily unattainable. On the contrary, the research in many laboratories throughout the world is directed towards this end. It is the chemical aspect of this research which I will cover in this lecture.

\section{MORPHINE AND MORPHINAN DERIVATIVES}

In order to gain historical perspective in this subject, it is necessary to relate the comment of Thomas Sydenham, the 17th century pioneer of English Medicine: 'Among the remedies which it has pleased Almighty God to give to man to relieve his sufferings, none is so universal and so efficacious as opium.'

Indeed opium is efficacious in relieving pain although Sydenham and several generations of practitioners following him did not recognize the chemical principle responsible for this effect. It was not until 1805 that Sertürner isolated this principle in pure crystalline form and determined that it constitutes about 10 per cent of opium. This substance was named morphine and its isolation marks the beginning of alkaloid chemistry. The chemical investigations on the structural elucidation and modification of this substance are well documented and form a fascinating account of the power of classical organic chemistry to unravel the structural complexities associated with this substance ${ }^{3}$. In addition, a tremendous effort was made to dissect this molecule to separate the useful analgetic effects from the undesirable addiction liability ${ }^{4}$.

In Figure 1 are shown the structures of morphine (I) and two of its congeners which are also present in opium. Heroin (III) is more strongly addicting than morphine while codeine (II) is very much less so than the parent compound. Nevertheless, all three drugs cause a marked respiratory depressant effect. Morphine consists of a complex five-ring system, with certain peripheral groups, which is subject to attack at many points. Also one can see within its structure any one of several basic ring systems which may be responsible for its physiological properties. The extensive work of Small ${ }^{5}$ and coworkers led to the following general conclusions: (i) etherification of the phenolic hydroxy group increases the convulsant action and decreases the analgetic activity by one tenth; (ii) saturation of the $\Delta^{7,8}$ 
double bond causes a slight increase in analgetic effect; (iii) modification of the 6-secondary hydroxyl group (ketonization or full saturation) increases toxicity, convulsant action and analgetic activity; (iv) opening the ether bridge diminishes activity. Additional studies also revealed that the $N$ methyl group was not absolutely essential for analgetic effects. In fact, replacement of methyl with the allyl group gave rise to nalorphine which is a powerful antagonist of morphine-like analgetics.

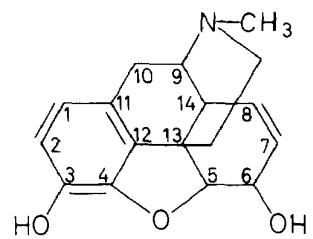

(I)

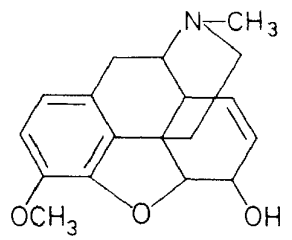

(II)

Morphine

Codeine

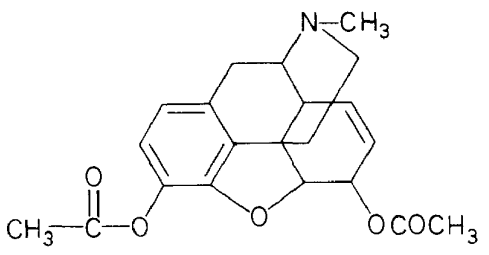

(III)

Heroin

Figure 1

During 1967 a series of excellent reports have appeared from the laboratory of Professor K. W. Bentley ${ }^{6-9}$ on the Diels-Alder addition of certain $\alpha, \beta$-unsaturated ketones to thebaine (IV). For example, the primary adduct of thebaine and methyl vinyl ketone consists almost entirely of the 7 - $\alpha$-ketone derivative (see Figure 2).

The most interesting group of substances in the 6,14-endoetheno-tetrahydrothebaine series (generically referred to as the oripavine analogues) is of the general structure (VIa). Bentley et al. have noted that if one keeps $R$ and $R^{\prime \prime}$ constant, increasing $R^{\prime}$ from $H$ through $\mathrm{CH}_{3}$ and $\mathrm{C}_{2} \mathrm{H}_{5}$ to $\mathrm{C}_{3} \mathrm{H}_{7}$ leads to a progressive increase in analgetic activity. The most potent analgetics were found in the phenolic series. A reduction in the 6,14-etheno bridge had little effect on activity. Bentley also observed that a reversal of the stereochemistry at $\mathrm{C}_{19}$ quaternary carbon in the side chain no longer influenced the variation of $\mathrm{R}^{\prime}$ relative to analgetic activity. Thus, in this series Bentley was able to prepare one compound $\mathrm{R}=\mathrm{H}, \mathrm{R}^{\prime \prime}=$ methyl and $\mathrm{R}^{\prime}=\mathrm{n}$-propyl which was 10000 times more potent than morphine when tested in experimental animals. However, this and related substances 
in this series were strongly addicting and thus have not had clinical application $^{10}$.

The synthesis of metamorphinan, an interesting variation of the morphinan molecule, was achieved by Gates and Klein ${ }^{11}$ as shown in Figure 3.

The reduction of thebaine by hydrogen over palladium afforded metathebainone (VII) which was converted in turn with sodium amalgam to dihydrometathebainone. After establishing the stereochemical relationship between rings $B$ and $\mathrm{C}$ by chemical and spectral methods, Gates and Klein further reduced 8 to 9 by means of a Wolff-Kishner reaction.

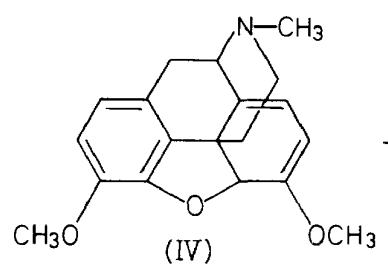

Thebaine

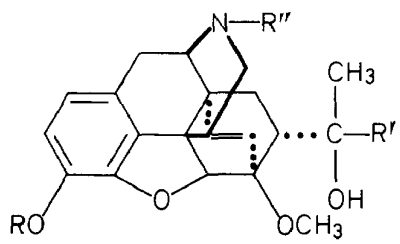

(VIa)

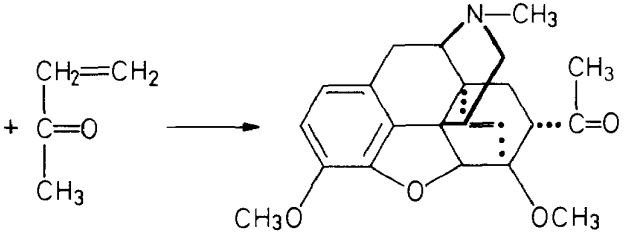

(V)
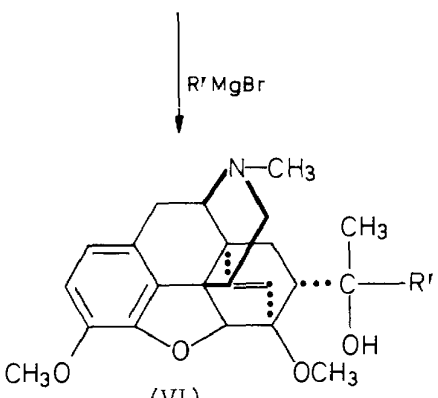

(VI)

Figure 2

The phenolic hydroxyl group was removed and the resulting 3-methoxy$N$-methylmetamorphinan was transformed to the corresponding 3-hydroxy$N$-methylmetamorphinan (XI). This substance was found to be inactive as an analgetic. The 3-hydroxy- $N$-cyclopropylmethylmetamorphinan was also prepared according to well established methods. The narcotic antagonist activity of this substance was virtually nil. The lack of activity of both of these compounds lends confirmation to the hypothesis of Braenden, Eddy and Halbach ${ }^{12}$ that a phenyl group or group isosteric with phenyl linked directly to a quaternary carbon is a necessary structural feature of all potent analgetics.

The recent work of Sargent and Joshi ${ }^{13}$ on the synthesis of a new position isomer of dihydromorphinone further demonstrates how critical the relative points of linkage of the ethanamine system are in respect to analgetic activity.

The synthesis as outlined in Figure 4 uses dihydrocodeinone as a starting material. The whole rationale, as herein illustrated, is to break the carbonnitrogen bond at $\mathrm{C}_{9}$ according to a Hofmann degradation and then to create 

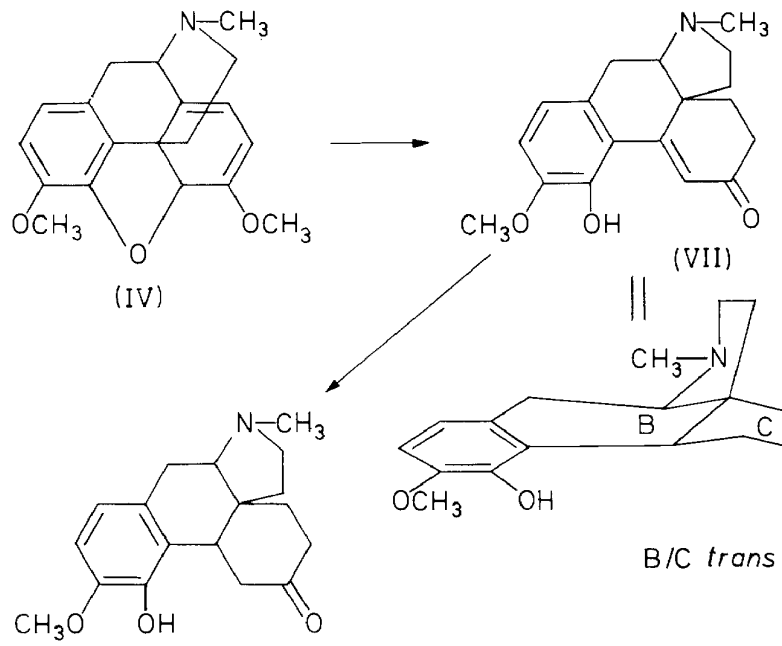

(VII)

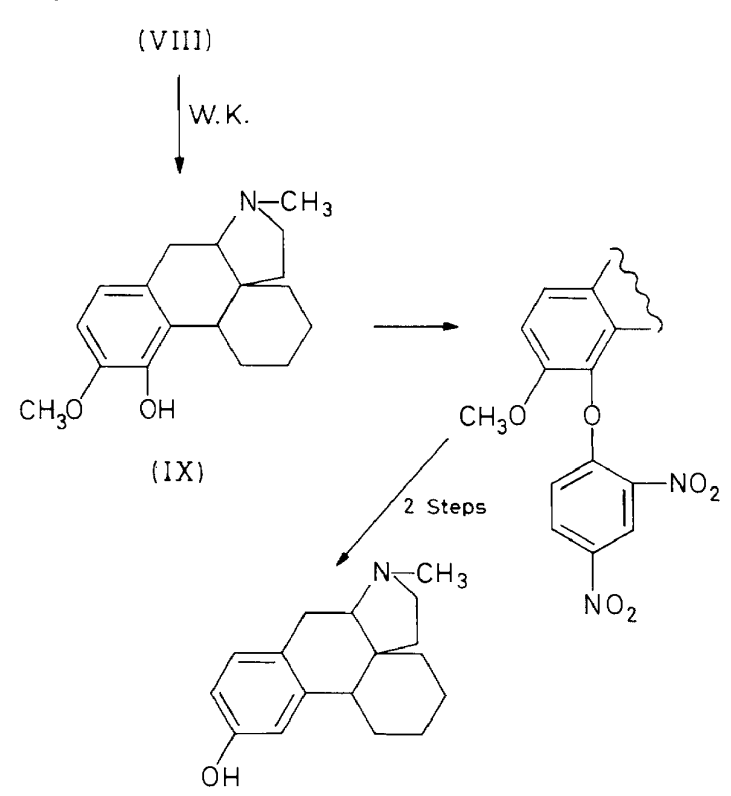

$(X)$

(XI)

Figure 3

a new carbon-nitrogen bond at $\mathrm{C}_{7}$ through the intermediacy of a readily replaceable active group. To this end, the $\alpha$-bromoketone (XIV) was prepared. Base-induced intramolecular cyclization of this properly constituted $\alpha$-haloamine yielded XV. Hydrogenolysis of the bromine, pyrolysis of the quaternary salt and conversion to the phenolic compound afforded the desired dihydromorphinone (XVI). In mice this substance elicited roughly one-third the analgetic activity of codeine. 


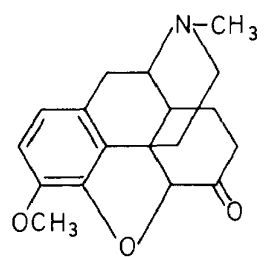

(XII)

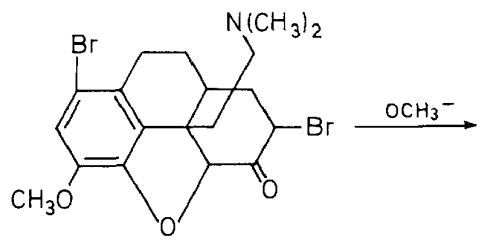

(XIV)

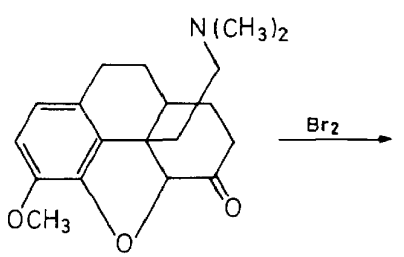

(XII)

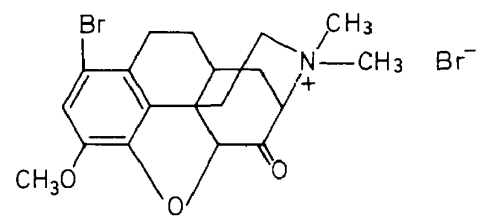

(XV)

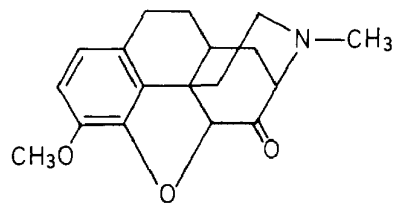

(XVI)

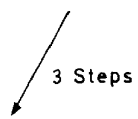

Figure 4

\section{6,7-BENZOMORPHANS (NARGOTIC ANTAGONISTS)}

Indeed the dissection of the morphine molecule has afforded a variety of compounds with a wide spectrum of analgetic activity and also deleterious side effects. However, one group of compounds obtained within the past decade has offered considerable hope that the so-called 'ideal' analgetic may be obtained therein. As illustrated in Figure 5, the construction of a tricyclic system incorporating rings $\mathrm{A}, \mathrm{B}$ and $\mathrm{E}$ of morphine gives rise to the 6,7-benzomorphans (XVII). This ring system was originally synthesized in ten steps by Barltrop ${ }^{14}$ in 1947. However, the compound in this class which most closely approximates the morphine ring system structurally and stereochemically is $\alpha$-2,5,9-trimethyl-2'-hydroxy-7,7-benzomorphan (XXII). May and associates ${ }^{15}$ reported the synthesis of this compound in 1959 and his method as outlined in Figure 6 has been widely used in the preparation of derivatives of this substance. That the predominant product was the $\alpha$-form was shown by methiodide reaction rate data. Quaternization of the $\alpha$-compounds with methyl iodide occurred from five to ten times as 


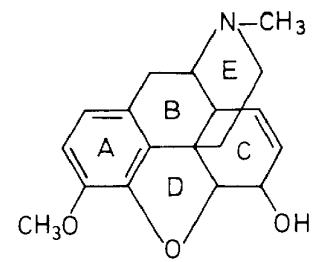

(I)

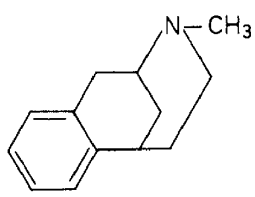

(XVli)

Morphine

Figure 5

rapidly as the $\beta$-counterparts. This could only mean that in the $\alpha$-compounds the 9-methyl group is oriented away from the nitrogen of the iminoethano system. This then results in a cis diaxial fusion at the 5,9-positions such as is the case in morphine and the morphinans.

Shortly thereafter Sydney Archer ${ }^{16}$ at Sterling-Winthrop developed an excellent working hypothesis for the further exploration of derivatives of this substance. His attack on the problem was both novel and daring. His argument was as follows (see Figure 7).<smiles>Cc1cc[n+](C)cc1C</smiles>

(XVII)<smiles>COc1ccc(CC2C(C)=C(C)CCN2C)cc1</smiles>

$(X X)$
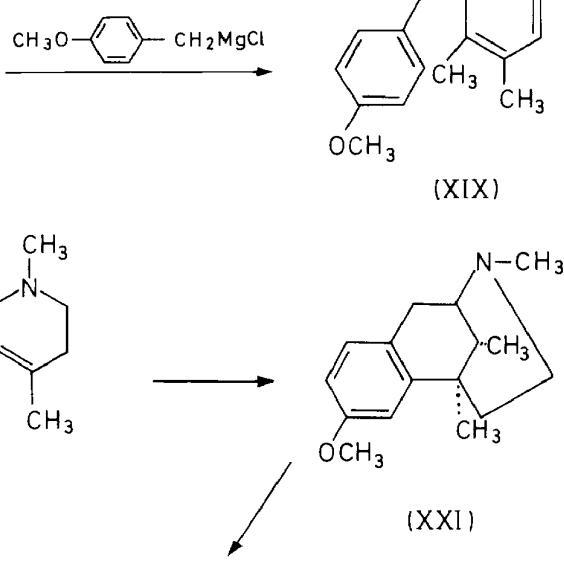

(XXI)

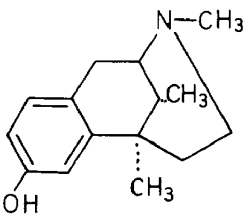

(XXII)

Figure 6 
It became clear, that, in order to achieve the desired separation of analgetic potency from addiction liability, the classical approach to the problem had to be abandoned. This notion was strongly supported by the highly important but generally neglected case of nalorphine (XXIII). Not only is this drug negative in the usual analgetic assays, but it actually antagonizes the effects of morphine and its congeners. Yet Keats and Telford ${ }^{17}$ were able to confirm the observations of Lasagna and Beecher ${ }^{18}$ that this drug was a potent analgetic in man, approximately equivalent in milligram-potency to morphine. Isbell ${ }^{19}$ was unable to produce addiction with this drug. Thus a strong analgetic, free of addiction liability, was

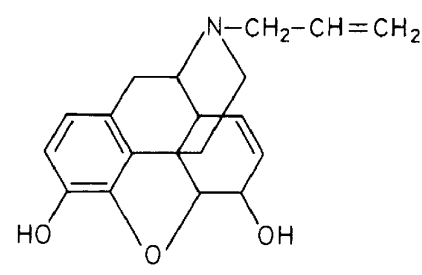

(XXIII)

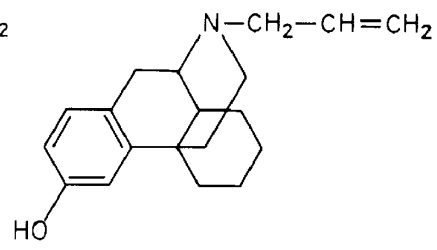

(XXIV)

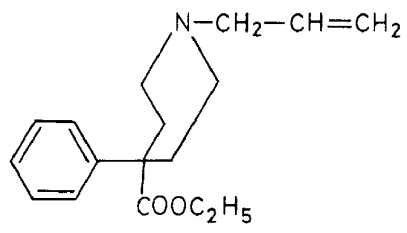

$(X X V)$

Figure 7

finally at hand. The high incidence of side effects, particularly of a psychotomimetic nature, precluded the use of this drug as a substitute for morphine. In pursuing this line of attack, Keats studied a varied and heterogeneous collection of analgetic antagonists for their analgetic effects in man. For one reason or another, none was considered to be an acceptable drug.

Replacement of the methyl group of morphine by an allyl radical furnishes nalorphine (XXIII), a potent narcotic antagonist. A similar manipulation in the morphinan series gives levallorphan (XXIV), a more potent narcotic antagonist. However, $N$-allylnormeperidine $(\mathrm{XXV})$ is an analgetic, not an antagonist.

The pharmacological properties of these drugs may be correlated with any of the following structural features: (a) the number of rings in the molecule-(XXIII) is pentacyclic, (XXIV) is tetracyclic, while (XXV) is only bicyclic; (b) the presence of a phenethylamine fragment in (XXIII) and (XXIV) which is not present in (XXV); (c) the non-planarity of XXIII and XXIV as compared with XXV. The synthesis and biological evaluation of a tricyclic derivative, such as a benzomorphan would be of 
interest because, if such a drug were inactive as an antagonist, then the important structural feature correlating with biological activity would be the number of rings in the molecule. Another reason for studying the benzomorphan series was the high clinical interest shown in phenazocine at the inception of this work.

It was Archer's aim to prepare a series of analgetic antagonists of varying potency by suitable substitution on a benzomorphan nucleus such as XXII. If activity were found, then, on the basis of appropriate pharmacological and toxicological studies in animals, a few members of the series of differing biological profiles would be selected for analgetic assay in man. A major pharmacological requirement was that all the putative drugs must be negative in the D'Amour-Smith test.
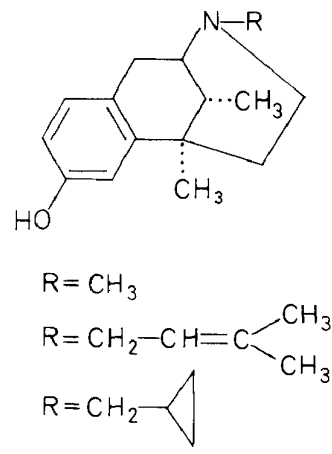

(XXII)

(XXVI)

(XXVII)

Figure 8

The synthesis of XXII ( $\mathrm{R}=\mathrm{CH}_{3}$ ), the cis or $\alpha$-isomer, was previously reported by May and his associates and Archer's task consisted of preparing the requisite derivatives by either alkylation with the appropriate halide such as dimethylallyl bromide to furnish pentazocine (XXVI) or by acylation with an acid halide such as cyclopropylcarbonyl chloride followed by lithium aluminium hydride reduction to give the desired (XXVII). From this work has resulted pentazocine which is an effective narcotic antagonist. In exhaustive clinical tests it has been shown to be devoid of addiction liability. Nevertheless, it has proven to be as potent as morphine in alleviating severe pain. Thus, it is the first really potent non-addicting analgetic $^{20}$. It is active by the intravenous and oral routes and causes some respiratory depression.

Recently, Clarke and coworkers ${ }^{21}$ at Geigy have prepared 6,7-benzomorphans with a phenyl substituent at the 5 position. The synthesis of this compound from 3-methyl-4-phenylpyridine methiodide (XXVIII) follows essentially the same route described by May (see Figure 9). However, the ring closure reaction to afford the tricyclic system is reported to go in higher yield than the corresponding May intermediate. The reason for this is suggested to be that the carbonium ion generated prior to ring closure is stabilized by the phenyl group. Predominantly the $\beta$-form (XXXI) is obtained in this cyclization. 
Gompounds XXXII and XXXIII have both been clinically evaluated and both are reported to be orally effective ${ }^{22}$. The $N$-carboxamide (XXXII) is equal to codeine in its analgetic action but is not addicting. Compound XXXIII is a potent narcotic antagonist; its analgetic activity is considered to be 5 times that of morphine. Although it is devoid of addiction liability, this compound has been found to cause respiratory depression. Two other syntheses of 5-phenyl-6,7-benzomorphans have been reported. In Figure 10<smiles>COc1ccc(CC(Cl)Cl)cc1</smiles>

(XXVIII)

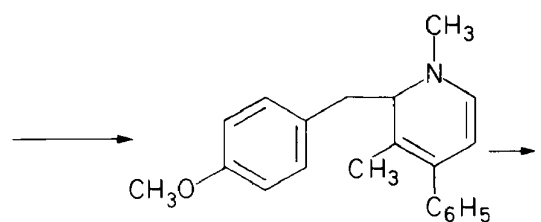

$(\mathrm{XXIX)}$

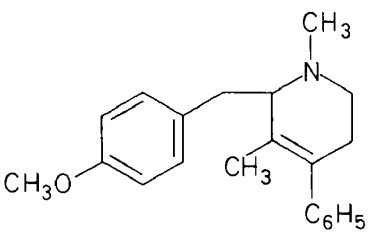

$(X X X)$<smiles>CCCCCc1cc[n+](C)cc1C</smiles>

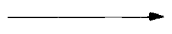

(XXXII)

$\mathrm{R}=\mathrm{CH}_{2}-\mathrm{CH}=\mathrm{CH}_{2} \quad(X \times X I I I)$

Figure 9

is outlined a second synthesis of this ring system by Clarke and his associates $^{23}$ and in Figure 11 the method devised by Schenker ${ }^{24}$ and Walker ${ }^{25}$ from CIBA is shown. The Schenker-Walker synthesis is unique in that it permits the preparation of 5,6, and 7-membered $\mathrm{E}$ rings.

Early this year May $^{26}$ reported the synthesis of 6,7-benzomorphan, the parent structure of this class of compounds, from 2-carbethoxy-4-phenyl pyridine (XXXIX). The key intermediate in this synthesis is 2-carboxy-1-methyl-4-phenyl piperidine (XL) which is allowed to undergo an intramolecular Friedel-Crafts type cyclization to generate 2-methyl-8-oxo6,7-benzomorphan (XLI). Wolff-Kishner reduction of the ketone yielded the 2-methyl-6,7-benzomorphan (XLII).

An interesting modification of the benzomorphan nucleus has been 
<smiles>CCCCCCC1CCC(=O)c2ccccc21</smiles>

$(X X X I V)$<smiles>CCCCCCC1CC(Br)C(=O)c2ccccc21</smiles>

$(X X X V)$

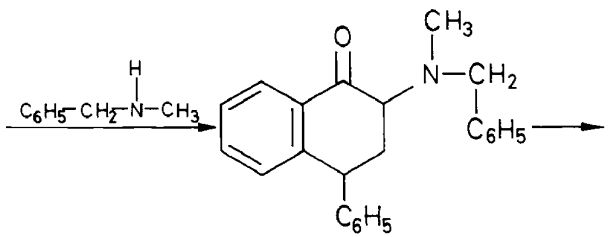

(XXXVI)

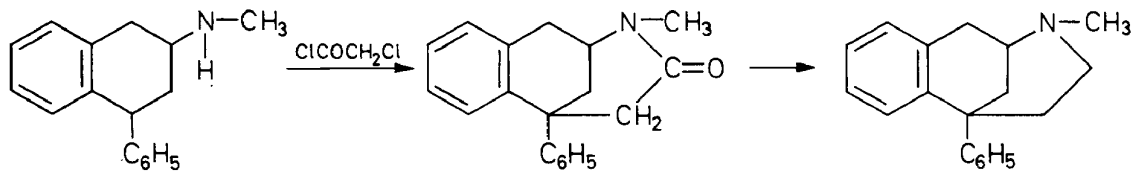

(XXXVII)

$(X X X V I I 1)$

$(X X X I X)$

Figure 10

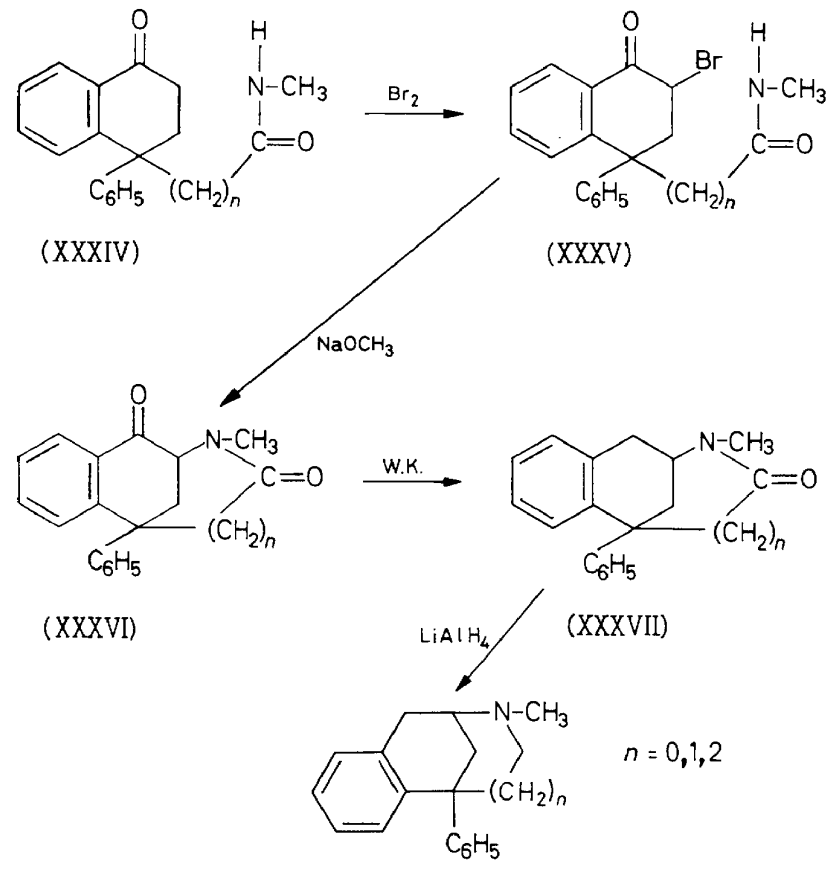

(XXXVIII)

Figure 11 


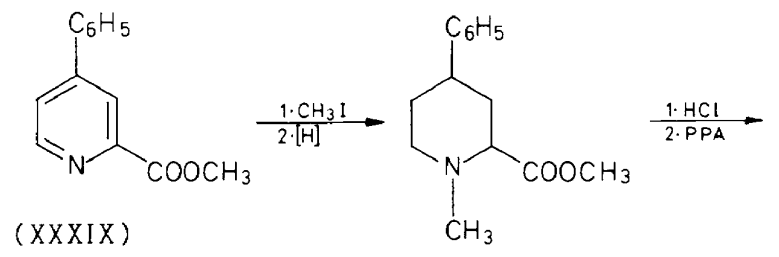

(XL)

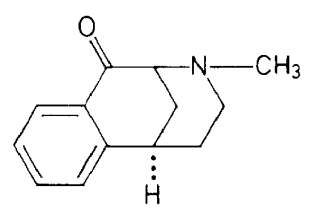

$(X L I)$

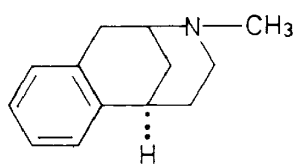

(XLII)

Figure 12

reported by Kametani and coworkers ${ }^{27}$. They prepared 1,2,3,4-tetrahydro$6 \mathrm{H}-1,5$ (e) (1,4)diazocine (XLVI) and 1,2,3,4,5,6-hexahydro-2,6-methanobenzo(e) $(1,4)$ diazocine (L). The synthesis of each of these heterocyclic ring systems is shown in Figures 13 and 14. In each of these cases a nitrogen atom has been substituted in the ring system in place of the quaternary carbon atom at position 5 . As yet reports on the analgetic activity of these azabenzomorphans have not been forthcoming.

Before closing the discussion on narcotic antagonists, it is most essential to say a few words on Naloxone (LI) (see Figure 15).

Pharmacological studies would indicate that this compound represents the most nearly pure antagonist of the compounds yet tested. It is practically<smiles>CC(=O)C1CC(C(N)=O)Nc2ccccc21</smiles>

(XLITI)<smiles>NCC1CC(CCl)c2ccccc2N1</smiles>

$(X L V)$

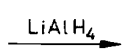<smiles>NCC1CC(CO)c2ccccc2N1</smiles>

(XLIV)<smiles>c1ccc2c(c1)NC1CNCC2C1</smiles>

(XLVI)<smiles>CCCCCCCC</smiles>

Figure 13 


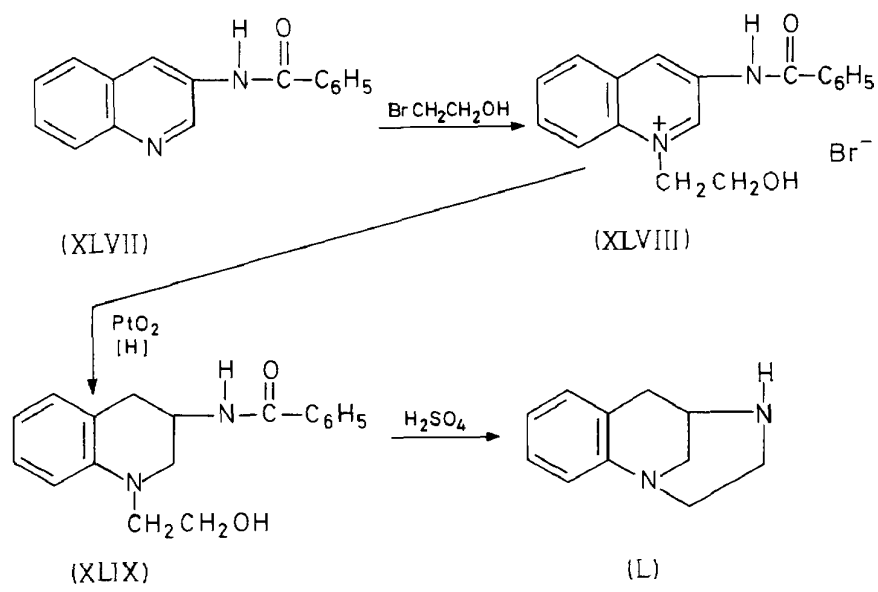

Figure 14

devoid of analgetic activity in animals ${ }^{28,29}$. The compound only rarely produces psychotomimetic effects and unlike nalorphine and cyclazocine shows few withdrawal signs after abrupt cessation of chronic medication. The ability of naloxone to relieve pain in man is still under study.

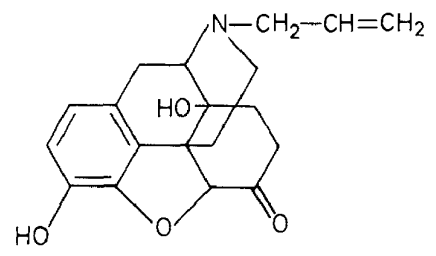

(LI)

Naloxone

Figure 15

\section{PIPERIDINE DERIVATIVES}

One of the heterocyclic systems which has received tremendous attention in analgetic research in the past 30 years has been the piperidine ring system. It has been stated that since Eisleb and Schaumann ${ }^{30}$ reported on the potent analgetic meperidine (LII) in 1939, over 4000 derivatives of this group of piperidines have been prepared and evaluated for their analgetic properties. Although many of these substances have shown analgetic effects, for the most part it really has not been possible to obtain a compound devoid of addiction liability and respiratory depression. For example, Cavalla et $_{\text {al. }}{ }^{31}$ at Parke, Davis and Co. have prepared a large number of pyrrolidine derivatives related to meperidine. The compound of choice was found to be prodilidene (LIII) (see Figure 16). Clinical trials indicated that 
<smiles>CCOC(=O)C1(c2ccccc2)CCN(C)CC1</smiles>

(LII)<smiles>CCCCC1(CCC)CCN(C)C1C</smiles>

(LIII)<smiles>CCCCCCCC1(c2cccc(O)c2)CCN(C)C1C</smiles>

(LIV)

Figure 16

the effective dose was 50-100 mg every 4 hours showing an activity equivalent to codeine. Recently the pharmacological properties of the prodilidene analogue (LIV) were reported ${ }^{32}$. The analgetic effect of this compound in experimental animals was found to be ten times greater than prodilidene, thus putting it in the same class with morphine. However, its effect in animals was antagonized by nalorphine.

An unusual and unexpected result has been brought forth by Kugita and coworkers $^{33}$ by the method outlined in Figure 17. They prepared a series of<smiles>COc1cccc(C(C)C(C)=O)c1</smiles>

(LV)<smiles>C#C[CH-]CCCC(C)(C(C)=O)c1cccc(OC)c1</smiles>

(LVI)<smiles>COc1cccc(C2(C)CCCNC2C)c1</smiles><smiles>CC1NCCCC1(C)c1cccc(O)c1</smiles>

(LVII)

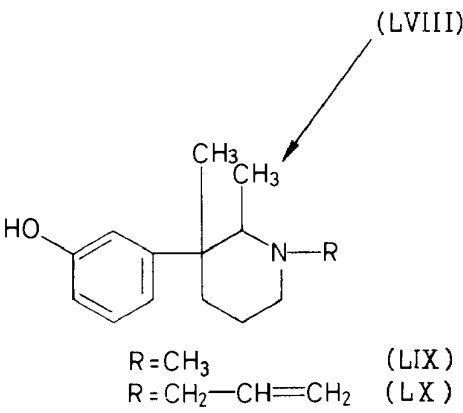

Figure 17 
meta-aryl substituted piperidines which exhibited excellent analgetic properties. The $N$-methyl derivative (LIX) was found to be as potent as morphine, but contrary to expectations, the $N$-allyl derivative (LX) was devoid of analgetic action and proved to be a narcotic antagonist. This antagonist effect was considered by Archer and Harris to be due to the phenethylamine fragment of the molecule ${ }^{34}$.

\section{TETRAHYDROISOQUINOLINES}

Three variations of 1-(4-chlorophenethyl)2-methyl-6,7-dimethoxy-1,2,3,4tetrahydroisoquinolines (methopholine; LXI), first prepared by Brossi ${ }^{35}$, have been synthesized for analgetic evaluation. These are outlined in Figure 18. Compound LXII was prepared by Gootjes and coworkers ${ }^{36}$,

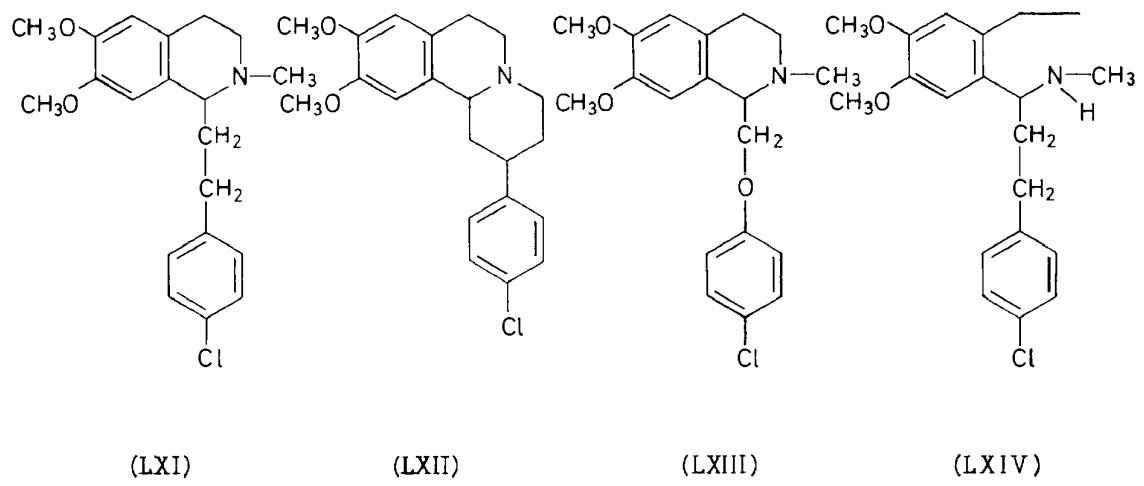

Figure 18

compound LXIII by Jirkovsky and Protiva ${ }^{37}$ and the Brossi group ${ }^{38}$ prepared compound LXIV. None of these substances proved to be superior to methopholine as an analgetic.

\section{QUINAZOLINES}

Within the past two years the quinazolines have also been a source for some new analgetics (see Figure 19). Within the CIBA Laboratories, Blatter has prepared some 4-amino substituted compounds and their analgetic effects have been reported by Chernov, Blatter and coworkers ${ }^{39}$. The most effective compound was 4-(2-dimethylaminoethylamino)quinazoline (Su13026) (LXV). This compound showed analgetic properties virtually equivalent to codeine in experimental animals; however, after extensive clinical trials, it proved to be a rather weak pain relieving substance.

Okumura and associates ${ }^{40}$ recently reported their work on the synthesis and pharmacological properties of the 1-acyl derivatives 2-methyl-3phenyl-4-oxo-1,2,3,4-tetrahydroquinazolines. Substance LXVI appeared to be the most active compound. However, its potency was found to be similar to that of aminopyrine and it had a shorter duration of action. No clinical data have been available on this compound. 

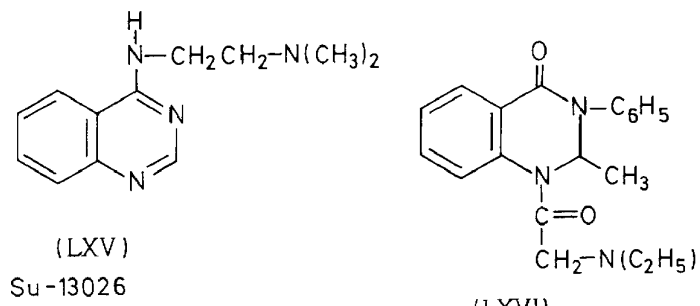

(LXVI)<smiles>C=CCN1Cc2ccccc2N(C(=O)CCCCCCCC)CC1C</smiles>

(LXVII)

Figure 19

Within this category may be considered the antagonist (LXVII) reported by Carabateas and Harris ${ }^{41}$. Although this compound is not as potent as nalorphine in antagonizing the effects of morphine, it nevertheless represents a new class of narcotic antagonist and may offer compounds of interest in the future.

\section{GARBOXYLIG AGID DERIVATIVES}

The synthesis and other chemical aspects of the substances discussed in this section are well worked out and will not be considered. The structures under discussion are presented in Figures 20-22.

The clinical significance of salicylic acid and derivatives for the treatment of mild to moderate pain has been appreciated for well over a century. In particular, 0 -acetylsalicyclic acid is a drug which has enjoyed the greatest success for the longest period of time in the history of medicinal chemistry. Generally known as aspirin, the pharmaceutical industry in the United States alone now manufactures over 30 million pounds of this drug per year.

Within recent years a variety of aromatic organic acids have been reported to elicit analgetic effects. Scherrer, Winder and Short ${ }^{\mathbf{4 2}}$ have given data to show that mefenamic acid (LXVIII) and Cl-583 (LXIX) not only are anti-inflammatory agents but also are analgetics more active than aspirin.

Juby and Hudyma ${ }^{43}$ have also prepared 4-anilinopyrimidine-5-carboxylic acids (LXX) and Evans et al. ${ }^{\mathbf{4 4}}$ have reported on the 2-anilinopyridine-3carboxylic acids (LXXI). These compounds have analgetic effects similar to the mefenamic acid group.

Compound LXXII (namoxyrate) has been reported by Corgill et al. ${ }^{\mathbf{4 5}}$ and by Emele and Shanaman ${ }^{46}$ to be a moderately potent clinically effective well tolerated non-narcotic analgetic equipotent to codeine. Clinical trials are still in progress with this substance. 
<smiles>Cc1cccc(Nc2ccccc2C(=O)O)c1C</smiles>

(LXVIII)

Mefenamic acid<smiles>Cc1cccc(Nc2ncncc2C(=O)O)c1C</smiles>

(LXX)<smiles>Cc1ccc(Cl)c(Nc2ccccc2C(=O)O)c1Cl</smiles>

(LXIX)

$\mathrm{Cl}-583$<smiles>Cc1c(Cl)cccc1Nc1ncccc1C(=O)O</smiles>

(LXXI)

SCH 10304

Figure 20

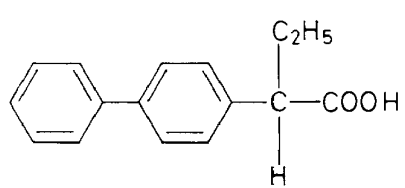

(LXXII)

Namoxyrate<smiles>COc1ccc2c(c1)c(CC(=O)O)c(C)n2C(=O)c1ccc(Cl)cc1</smiles>

(LXXIII)

Indomethacin

Figure 21 
GEORGE DESTEVENS

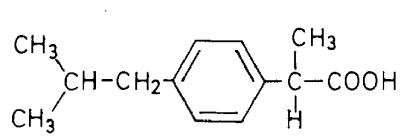

(LXXIV)

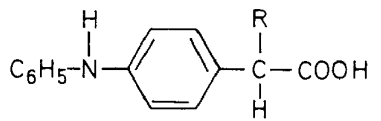

$\mathrm{R}=\mathrm{H}, \mathrm{alk} \mathrm{yl}$

(LXXVI)

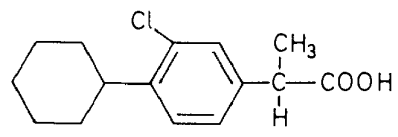

(LXXV)

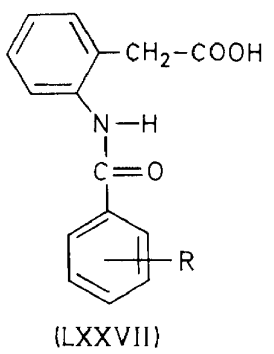

Figure 22<smiles>Cn1c2c(c3ccccc31)CCN1CC3CCCCC3CC21</smiles>

$(\text { IXXVIII) })^{52}$

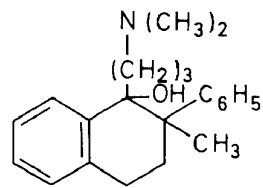

$(\mathrm{LXXX})^{54}$<smiles>CC(C)C(CCN(C)C)(C(N)=O)c1cccc2ccccc12</smiles>

(LXXIX) $)^{53}$<smiles>O=c1oc2ccccc2c(=O)n1CCN1CCN(c2ccccc2)CC1</smiles>
(LXXXI) $)^{55}$
$\mathrm{CH}_{3}-\left(\mathrm{CH}_{2}\right)_{3}-\mathrm{O} \longrightarrow \mathrm{CH}_{2}-\stackrel{\mathrm{C}}{\mathrm{C}}-\mathrm{NHOH}$

$(L X X X I I)^{56}$<smiles>CCN(CC)CCC/C(=N\OC(N)=O)c1ccc(OC)cc1</smiles>
$(\mathrm{LXXXIII)})^{57}$

Figure 23 
Indomethacin (LXXIII), a new potent anti-inflammatory agent, has also been reported by Winter ${ }^{47}$ to be about 10 times more potent than aspirin as an analgetic.

Other acetic acid derivatives which have been described in the literature to have analgetic properties are compounds (LXXIV) ${ }^{48}$, (LXXV) ${ }^{49}$, $(\mathrm{LXXVI})^{50}$ and (LXXVII $)^{51}$. No clinical data are at present available on these substances.

\section{MISCELLANEOUS}

Finally, within the miscellaneous class diverse structures have been cited to be analgetically effective in experimental animals. The structures of these compounds are shown in Figure 23. No significant clinical data are as yet available.

In conclusion, I would like to emphasize that the degree of commitment to analgetic research in the past three years has been as great as in any comparable time before 1965. Some new chemistry and chemical structures with unexpected analgetic properties have evolved from this work. In some cases it is too early to predict the eventual importance of some of these substances in clinical practice. The narcotic antagonists offer for the first time substances devoid of addiction liability; however, other morphine side effects have not been completely eliminated. A potentially exciting area is the aromatic and heterocyclic acids group. Although, as pointed out by Dr. Winter, the analgetic effect of some of these substances is peripheral, the opportunity of finding an outstanding analgetic amongst this chemical class is very great provided some of the alarming side effects reported can be eliminated. And finally, with so much new chemistry being generated throughout the many laboratories engaged in pharmaceutical research, the hope always remains that a completely new chemical substance will emerge with outstanding analgetic effects.

\section{References}

${ }^{1}$ G. deStevens (ed.). Analgetics, Academic Press, New York (1965).

${ }^{2}$ C. C. Pfeiffer. Mod. Hosp. 76, 100 (1951).

${ }^{3}$ D. Ginsburg. The opium alkaloids, Interscience Publishers, New York (1962).

${ }^{4}$ E. L. May and L. J. Sargent. In Analgetics (G. deStevens, ed.), Academic Press, New York, pp. 123-177 (1965).

${ }^{5}$ L. F. Small, N. B. Eddy, E. Mosettig and C. K. Hummelsbach. Studies on drug addiction, Public Health Dept., Suppl. 138 (1938).

${ }^{6}$ K. W. Bentley and D. G. Hardy. J. Am. Chem. Soc. 89, 3267 (1967).

7 K. W. Bentley, D. G. Hardy and B. Meek. J. Am. Chem. Soc. 89, 3273 (1967).

${ }^{8}$ K. W. Bentley and D. G. Hardy. J. Am. Chem. Soc. 89, 3281 (1967).

${ }^{9}$ K. W. Bentley, D. G. Hardy and B. Meek. J. Am. Chem. Soc. 89, 3293 (1967).

10 M. Gates. Sci. Am. 215 (No. 5), 131 (1966).

11 M. Gates and D. A. Klein. J. Med. Chem. 10, 380 (1967).

12 O. J. Braenden, N. B. Eddy and H. Halbach. Bull. World Health Organ., 13, 937 (1955).

${ }_{13}$ L. J. Sargent and B. G. Joshi. J. Med. Chem. 11, 336 (1968).

14 J. A. Barltrop. J. Chem. Soc. 399 (1947).

15 E. L. May and N. B. Eddy. J. Org. Chem. 24, 294, 1435 (1959).

${ }^{16}$ S. Archer, N. F. Albertson, L. S. Harris, A. K. Pierson and J. G. Bird. J. Med. Chem. 7, 123 (1964). 


\section{GEORGE DESTEVENS}

17 A. S. Keats and J. Telford. J. Pharmacol. Exptl. Therap. 117, 190 (1956).

${ }^{18}$ L. Lasagna and H. K. Beecher. J. Pharmacol. Exptl. Therap. 112, 356 (1954).

${ }^{19}$ H. Isbell. Federation Proc. 15, 442 (1956).

20 A. S. Keats and J. Telford. J. Pharmacol. Exptl. Therap. 143, 157 (1964).

21 F. Glarke, Medicinal Chemistry Symposium on Newer Analgetics and Narcotic Antagonists, 153rd Meeting of the American Chemical Society, Miami, Florida, April 1967.

${ }^{22}$ L. S. Harris and W. L. Dewey. Annual reports in medicinal chemistry, Chapt. 4, Analgetics, p. 35 (1967).

${ }^{23}$ J. R. Geigy A-G. Neth. Pat. Appl. 6606 057, Nov. 7, 1966. Chem. Abstr. 67, 21854e (1967).

24 K. Schenker. Belgian Pat. 665189 (1965).

${ }^{25}$ G. Walker and D. Alkalay. J. Org. Chem. 31, 1905 (1966).

${ }^{26}$ K. Kanematsu, R. T. Parfitt, A. E. Jacobson, J. H. Ager and E. L. May. J. Am. Chem. Soc. 90, 1064 (1968).

27 T. Kametani, K. Kigasawa, M. Hiiragi, H. Ishimaru and T. Hayasaka. Chem. Pharm. Bull. (Tokyo) 13, 295, 300 (1965).

${ }^{28}$ H. Blumberg, P. S. Wolf and H. B. Dayton. Proc. Soc. Exptl. Biol. Med. 118, 763 (1965).

29 J. Pearl and L. S. Harris. J. Pharmacol. Exptl. Therap. 154, 319 (1966).

30 O. Eisleb and O. Schaumann. Deut. Med. Wochschr. 65, 967 (1939).

${ }^{31}$ J. F. Gavalla, J. Davoll, M. J. Dean, C. S. Franklin and D. M. Temple. J. Med. Pharm. Chem. 4, 1 (1961).

${ }^{32}$ G. V. Winder, W. Welford, J. Wax and D. H. Kaump. J. Pharmacol. Exptl. Therap. 154, 161 (1966).

${ }^{33}$ H. Kugita, T. Oine, H. Inoue and G. Hayashi. J. Med. Chem. 8, 313 (1965).

34 S. Archer and L. S. Harris. Progress in Drug Research (E. Jucker, ed.), 8, 311-315 (1965).

35 A. Brossi, H. Besendorf, B. Pellmont, M. Walter and O. Schnider. Helv. Chim. Acta 43, 1459 (1960).

${ }^{36}$ J. Gootjes, A. B. H. Funcke and W. T. Nauta. Arzneimittel-Forsch. 17, 1145 (1967).

37 I. Jirkovsky and M. Protiva. Coll. Czech. Chem. Commun. 32, 1197 (1967).

38 A. Brossi and A. Rheiner, Jr. Swiss Pat. 410 007, Oct. 15, 1966. Chem. Abstr. 66, 28525m (1967).

${ }^{39}$ H. I. Chernov, H. M. Blatter, P. S. Bernard, D. E. Wilson and A. J. Plummer. Proc. Soc. Exptl. Biol. Med. 125, 747 (1967).

${ }^{40}$ K. Okumura, T. Oine, Y. Yamada, G. Hayashi and M. Nakama. J. Med. Chem. 11, 348 (1968).

41 P. M. Garabateas and L. S. Harris. J. Med. Chem. 9, 6 (1966).

42 R. A. Scherrer, G. V. Winder and F. W. Short, Ninth National Medicinal Chemistry Symposium of the American Ghemical Society, Division of Medicinal Ghemistry, June 21-24, 1964, University of Minnesota, Minneapolis, Minnesota.

43 P. F. Juby and T. W. Hudyma. J. Med. Chem. 10, 954 (1967).

${ }^{14}$ D. Evans, K. S. Hallwood, G. H. Cashin and H. Jackson. J. Med. Chem. 10, 428 (1967).

${ }_{15}$ D. A. Gorgill, C. W. Ligon and E. A. DeFelice. Current Therap. Res. 7, 263 (1965).

${ }^{46}$ J. F. Emele and J. E. Shanaman. Arch. Intern. Pharmacodyn. 170, 99 (1967).

47 G. A. Winter in Analgetics (G. deStevens, ed.), Academic Press, New York, Ghapt. II, p. 54-56 (1965).

${ }^{48}$ S. S. Adams, E. E. Cliffe, B. Lessel and J. S. Nicholson. J. Pharm. Sci. 56, 1686 (1967).

${ }_{49}$ T. Y. Shen, Second Middle Atlantic Regional American Chemical Society Meeting, Medicinal Chemistry Section, New York City, February 1967.

${ }^{50}$ Rhone-Poulenc S. A. Neth. Pat. App1. 6515 071, May 31, 1966. Chem. Abstr. 66, 2379 (1967).

51 T. J. Smith and Nephew Ltd. Neth. Pat. Appl. 6609 040, Dec. 30, 1966. Chem. Abstr. 68, 39332 (1968).

52 J. Shavel, Jr. and H. Zinnes. U.S. Pat. 3291 800, Dec. 13, 1966.

${ }^{53}$ G. Pala, S. Casadio, T. Bruzzese, E. Crescenzi and E. Marazzi-Uberti. J. Med. Chem. 8, 698 (1965).

${ }^{54}$ G. F. Turk and J. Krapcho. J. Med. Chem. 10, 823 (1967).

${ }_{55}$ Miles Laboratories, Inc. Neth. Pat. Appl. 6709 617, Nov. 11, 1967.

${ }^{56}$ G. Lambelin, R. Roncucci, M. J. Simon, S. Orloff, G. Mortier, E. Veys and N. P. Buu-Hoï. Arzneimittel-Forsch. 18, 56 (1968).

${ }^{57}$ M. J. Karten, B. Elpern and S. Rosen, Abstracts of 155 American Chemical Society Meeting, Medicinal Ghemistry Division, San Francisco, Galif., April 1-5, 1968. 